Wilfrid Laurier University

Scholars Commons @ Laurier

\title{
“How Can He Be So Cruel?" Examining Issues of Trust in School Improvement Efforts
}

Jacqueline R. Wettlaufer

Wilfrid Laurier University

Steve Sider

Wilfrid Laurier University, ssider@wlu.ca

Follow this and additional works at: https://scholars.wlu.ca/educ_faculty

Part of the Educational Leadership Commons, Elementary and Middle and Secondary Education Administration Commons, and the Other Teacher Education and Professional Development Commons

\section{Recommended Citation}

Wettlaufer, J. R. A., \& Sider, S. R. (2019). “How Can He Be So Cruel?” Examining Issues of Trust in School Improvement Efforts. Journal of Cases in Educational Leadership, 22(2), 3-13. https://doi.org/10.1177/ 1555458919826220

This Article is brought to you for free and open access by the Faculty of Education at Scholars Commons @ Laurier. It has been accepted for inclusion in Education Faculty Publications by an authorized administrator of Scholars Commons@ @aurier. For more information, please contact scholarscommons@wlu.ca. 
"How can he be so cruel?": Examining issues of trust in school improvement efforts

\begin{abstract}
In this case, a high school vice-principal encounters tension and anger when she re-writes a staff member's report card comments without his knowledge. The case narrative examines the conflict that arises when, under time constraints and pressures to produce student reports, the vice-principal acts on a decision she believes is ethically correct only to find that she incurs a significant setback with staffing relationships largely due to wavering of trust. The analysis examines how transformational leadership builds self-efficacy in all staff founded on trusting relationships. Professional reflection provides a conduit through which educational leaders can assess their own practice and implement the changes needed to sustain school improvement planning.
\end{abstract}


"How can he be so cruel?": Examining issues of trust in school improvement efforts Context

As with most educational jurisdictions, schools in Ontario, Canada have been engaged in School Improvement Plans (SIPs) and Professional Learning Communities (PLCs) over the past 20 years. Central to both is a focus on enhancing and improving student learning outcomes. SIPs are written documents that provide strategic direction for schools, usually in alignment with what a school district has determined as important aspects of student learning (Bernhardt, 2015). SIPs typically identify a specific area for improvement that will be the focus for the school staff over a year or more period of time. Examples of these areas might include character education, assessment to inform instruction, global competencies, and numeracy across the curriculum.

One way that school administrators can engage teachers in a School Improvement Plan is through Professional Learning Communities (PLC). PLCs (or Professional Learning Networks) are groups of educators who are brought together either through a common interest or a shared area of responsibility (Watson, 2014). For example, PLCs can be formed to examine issues such as technology across the curriculum or can be formed as a way for all History and Geography teachers to explore opportunities for inter-disciplinary focus areas. In this case study, teachers are formed into subject-area PLCs to address a new direction for report card writing. This means that all History teachers are part of one PLC, the Mathematics teachers another, and so on. The subject (department) head helped facilitate monthly meetings of the PLCs.

The school has identified assessment and evaluation, particularly the ways in which report cards provide information to students and their families, as an area of the SIP. In previous years, mid-term report cards had been produced with numeric grades and comments generated from a data bank of comments. Parents and guardians of students had complained that the 
generic nature of the comments was largely meaningless. As a result, the school administrative team, in consultation with the teachers, has decided to continue with numeric grades on mid-term report cards (November and April) but to encourage teachers to include comments that they generated themselves. Starting at the end of the previous school year, the administrative team provided information to the teachers about the change and indicated that further professional development would be provided in August when they returned to the school. They also indicated that PLCs would support the associated professional development activities by providing opportunities for collaboration, discussion, and fine-tuning of the process.

The school that is the focus of the case study, Mother Theresa Secondary School, is a Catholic school with students from grade 9-12. It is located in a rural community in a mid-sized school district in Ontario, Canada. Catholic schools are fully funded in Ontario. Mother Theresa SS has 1,300 students, $70 \%$ of whom are bussed to the school. There are 75 teachers and 20 support staff at the school. It is located in an agricultural community but one that is seeing increasing numbers of families relocate due to its proximity to a city of 500,000 people. The school has a mix of teachers who have been there for 20 or more years as well as those who are new to teaching. The principal has been at the school for six years and is planning on retiring at the end of the current year. The two vice-principals (VP) have responsibility for various portfolios including special education, athletics and extra-curricular activities, discipline, and assessment and evaluation.

The VP who is the focus of this case - Rachel - has been at the school for three years and is responsible for the SIP process and the current focus on descriptive report card writing. Interestingly, she started her teaching career at the school, for 10 years, before leaving to teach at a different high school for seven years. She completed her principal qualification process during 
that tenure and has now returned for her first VP role at her original school. As a result, she knows many of the teachers, having worked with them previously. The other central educator in this case - Bart, a History teacher - taught in the same department as Rachel when she was a teacher and they have had a positive, collegial relationship for many years.

\section{Case Narrative}

As the least experienced member of the three-person administrative team at a rural high school in Ontario, Canada, Rachel has slowly developed confidence in her ability to implement school improvement planning. Since she began her work as a vice-principal three years earlier, Rachel has taken pride in developing the School Improvement Plan with the help of the school data team. The school data team is comprised of teacher representatives from across all of the subject areas who meet four times per year with Rachel. The team discusses student achievement in each of their subject areas and look for areas of growth that are common to them all to help drive the agendas of the professional learning communities. School improvement planning had been implemented five years earlier in conjunction with a province-wide mandate to align board, school, and classroom practices to support student success. Concurrent with this implementation was an expectation to make decisions based on rich data to inform future directions. It had all been a whirlwind for many of the teachers in Rachel's school and they had come to respect Rachel's no-nonsense, efficient approach to sustaining best practice. They appreciated her efforts to ensure applicable professional development activities were connected with their daily instructional practices. Staff members had transitioned from a reluctant attitude toward the SIP to looking forward to monthly PLC meetings in which data were presented to show their progress in relation to the goals set within their school improvement plan. These 
PLCs were established in September for the purposes of addressing ongoing gaps in student achievement across the curriculum. The PLCs worked in tandem with the School Data Team to ensure implementation of changes to practice were strategic and had the desired impact. The implementation of the SIP had not been without its challenges, but the teachers were making tremendous strides in adopting effective, data-driven instructional practices.

Rachel recognizes that although each teacher may have differing levels of experience, it remains important that each strives to further align their professional practice with the SIP. To accomplish this, Rachel makes a point of visiting a number of classrooms each day to facilitate discussion about learning goals, success criteria, and descriptive feedback. This year's SIP focus is on the writing of descriptive reports that focus on student achievement. This has created quite the buzz in the staffroom. Rachel knew the staff would feel challenged about writing their own midterm report card comments (rather than choosing pre-written comments from a list like they did last June) so she planned ahead to book the school board's assessment consultant to lead two half-day professional development sessions on linking descriptive feedback to midterm report card comment writing. As she predicted, both sessions were easily filled to capacity and were comprised of teachers from across the subject areas. Rachel hoped that if $70 \%$ of the staff was able to take part in the learning that the remaining $30 \%$ would benefit from the candid conversations that occurred in the staff computer labs where the majority of mark entry took place.

The sessions went extremely well. Teachers engaged with the consultant to develop strategies for descriptive report writing. Rachel was part of numerous conversations during the professional development days in which teachers shared their ideas for how to best facilitate the work involved with providing the level of descriptive text. The instruction and interaction from 
the professional development days were further supplemented in the monthly PLCs. Subject (department) heads provided opportunity for discussion in the monthly PLCs to help subject teachers consider the kinds of comments they could incorporate into the report cards. They also provided sample language for the varying levels of student achievement. Rachel had attended as many of the PLCs as she could and, by the middle of October, thought the teachers were ready to engage in report card comment writing in the next few weeks leading to the mid-point of the academic term. She could not have been further from the truth.

It was evident to the administrative team that when sample midterm report card comments were taken from across the subject areas that there were huge gaps in the teachers' descriptive comments. Much of this seemed to emanate from the difficulty teachers were having with identifying student strengths and providing comments on areas of need. Rachel had been reviewing comments for three days now and had invited teachers into conversation about their written comments to facilitate individualized learning. It was 10:30 am on Wednesday and time was running out as the noon deadline was approaching for submitting changes prior to running the paper copies of the reports for signature and distribution to homeroom teachers. Of the subject areas that were assigned to Rachel, those from the teachers in the History department were the most distressing, especially Bart's, one of the long-serving History teachers. Bart was set to retire in June and over the past two years had given up the headship of the History department, had become increasingly quiet during professional collaboration, and had spent more time with assembly productions. It was evident that as he neared the end of his career he was less interested in teaching compulsory credit courses and increasingly preferred to spend his time with students who were inspiring and full of positive energy to produce well-received school-wide celebrations. 
As Rachel re-read Bart's comment on one of the reports, she sat back in her chair, hardly believing what she had read:

Darren is going to fail this class if he doesn't start doing his homework. His first step would be to buy a binder and then copy the notes from another student - but I don't have faith that this will happen. Darren should consider working full time instead of going to school and wasting my time.

How can he be so cruel? Rachel thought to herself. Yes, Darren had been into her office on multiple occasions, usually because Bart and a few other teachers would send him there when they became exasperated with the limited work he did in their classes. However, most were likely not aware of the challenging home situation that he experienced but of which Rachel had learned on one of her phone calls home.

Rachel continued in her thoughts, This will be devastating for his mother to read. Isn't there a better way to communicate with Darren's mom about this area of need? Rachel hunched over the report and could feel her palms getting sweaty as she thought about the consequence of this report being sent home. A quick look at the clock reminded her that her day was rapidly moving toward lunch hour when all of the students would be in the hallways and her presence would be needed.

Given the time constraint that now loomed, Rachel made the decision to edit several of Bart's comments prior to letting him know - after all, they had been teaching colleagues for many years. Rachel and Bart had been involved with professional learning related to assessment and reporting that spanned several government iterations, they co-coached the debating team, and they had creatively collaborated with students to successfully produce many school assemblies. Rachel respected Bart and knew what 
he intended to say so she used alternative parent and student-friendly language to convey the same meaning. She began writing...

A few minutes later, with report editing now finished, Rachel got up from her desk to cross the hall and head downstairs to speak personally with Bart. Just as she stepped foot outside the main office, she came upon two students exchanging loud words at the front door of the school. Rachel responded immediately but her efforts to prevent the fight were thwarted when the two boys began punching one another. In the ensuing minutes, students were separated, statements were taken, parents called, and police reports signed. Rachel worked with one of the parents intensively to help him understand the reasons for the subsequent suspensions.

Once all of the suspension notices had been written, Rachel opened her office door just in time to find Bart barging angrily toward her office with a stack of report cards in his hands. In a fury of words and action, he slammed the stack down on the desk and in a very loud daunting voice said, "When were you going to tell me you rewrote my report cards and what gives you the authority to do so? What gave YOU the right to change what I consider to be accurate and honest reporting on student achievement in MY classes? I observed these students all semester - not you!’. Anger and outrage continued, and despite the best of intentions and her wealth of experience, Rachel knew that he was right - she should have never caved in to the publishing deadline and should have spoken with him first. She had never been in a situation like this before and knew that in her eagerness to prevent issues with parents that she had let Bart down. Now what should she do? 


\section{Teaching Notes}

Trust and Professional Relationships

Central to transformational leadership in an educational community is the establishment of a foundation of trust in professional relationships (Bai, Ping Li \& Xi, 2012; Eyal \& Roth, 2011; Wahlstrom \& Seashore Louis, 2008). Successful educational leadership traits are dependent upon the presence of antecedent personal trust attributes (Gregory, 2017). Educators who observe social interactions that value each of their contributions to the team within an environment that cares for their holistic well being have reported that trust is significant to this relationship continuing to be productive (Bai et al., 2012).

In this case study, trust is the common factor that underlies the source of conflict. Trust takes time to build, usually through many interactions and situated experiences (TschannenMoran, 2014). It can also be quickly damaged when a person perceives that trust has been in some way broken. Relationships that lack the essence of trust are characterized by impeded communication leading to questions of credibility and competence due to inconsistency of practice (Bai et al., 2012). In this case, Rachel demonstrated inconsistency between the leadership she provided in the change process - engaging the school community through the SIP and PLCs to adapt report cards - with her individual response to Bart's written comments. Principals review the comments of teachers on report cards to ensure that they accurately and succinctly report on student achievement. If the principal is concerned that report card comments do not accurately reflect student achievement, it is the responsibility of the principal to address the concerns with the teacher and, if necessary, require that the comments be changed by the teacher. Trusting relationships in a school context are characterized by open communication, honesty, and integrity (Gurr, Drysdale \& Mulford, 2005). Rachel had 
maintained these characteristics through much of the change process but, in a pressure-filled situation, she resorted to an expedient solution that broke the professional trust and relationship with Bart.

Bart shares responsibility for the breaking of trust due to the insensitivity of the comments he had written. Bart has a responsibility to the student, the student's family, and to the school, to accurately, and sensitively, communicate both the strengths and the needs of the student at the mid-point of the term. Further, he was provided multiple opportunities, through the professional development sessions and the History PLC, to question and to understand the rationale and process for developing written report card comments. He had not engaged Rachel in this discussion and, as a result, had not demonstrated trust nor collegiality. Openness in communication leads to a shared understanding of perspectives and generates a healthier more productive environment that recognizes the efficacy of each stakeholder and the value of sharing best practices (Handford \& Leithwood, 2013; Helstad \& Moller, 2013; Poulou, 2017). Professional Ethics

Effectual school leadership relies, in part, on the ability of the principal to engage in courageous conversations in order to move the community towards the intended goals set for student achievement (Tschannen-Moran, 2014). When Rachel made the decision to rewrite Bart's comments without first informing Bart, she undermined her own credibility and called into question her instructional leadership competence due to a lack of regard for the professionalism and competence of teachers and the purposes of the PLC. There is also significant potential that she has by-passed professional ethical expectations of what it means to be a school leader (Mullen, 2017). Changing a teacher's comments on a report card, an official document, would be akin to changing a teacher's reflective comments on a performance 
appraisal or changing a teaching assignment that a teacher has agreed to without their knowledge. Demonstrating ethical leadership, through building and maintaining trust and having courageous conversations, is directly attributable to healthy work environments and teacher morale (Hanford \& Leithwood, 2013).

Equally as important is the nurturing of strong foundational relationships that rely on an understanding of the various applications of roles and responsibilities (Tschannen-Moran \& Gareis, 2015). The instructional leadership role of the vice-principal within the PLC facilitates and nurtures ongoing professional dialogue and timely learning within the context of providing an environment in which all members of the team share in the responsibility to ensure equity of access to growth opportunities. Teachers within the PLC invest in the professional learning thereby sustaining an environment in which the whole team continues with skills development. Additionally, the closer the social interactions between a principal and teachers are, the more likely that teachers will engage in a change process (Moolenaar et al., 2010). In this case, Rachel spent considerable time monitoring the change process within the PLCs but powerful opportunities to invest in deeper relationships by incorporating responsive professional learning were bypassed due to Rachel's busy schedule and convenience.

The role of school administrators can be incredibly complex and hectic (Northfield, 2013). It is common for school principals to have many competing demands on their time. For Rachel, she had an impending deadline for completing the report cards and was concurrently dealing with a significant student behavioural issue. It is quite likely that she had multiple other demands on the particular morning in which this case is situated. However, despite these pressures, or perhaps because of these pressures, it is critical that school principals maintain ethical standards of behaviour that do not usurp power or attempt to control circumstances in the 
name of expediency (Mullen, 2017; Walker, Kutsyuruba \& Noonan, 2011). This leadership lesson would be enhanced for Rachel through her own reflection and professional growth. Listening and Learning in Professional Development Opportunities

An antecedent that is evident in the transformational leadership model is the idea that shared leadership and strong community interactions are present (Gurr et al., 2005; Pashiardis, Kafa, \& Marmara, 2012). Rachel may have invested in professional development but it remains unclear as to whether she pursued the implementation of the shared leadership model to enhance the various professional learning communities. For example, Rachel used the PLCs as a way to communicate changes to the report card writing process but never provided a link between the professional development sessions and how the PLCs could support the change process, nor did she solicit feedback from the PLCs as to issues of resistance or concern. Rachel supported the use of PLCs as a way to communicate change but did not incorporate a feedback loop that would have provided her with insight into the concerns of the teachers. The motivation to engage in the change process is a direct reflection of the educational relationship style experienced (Eyal \& Roth, 2011).

PLCs provide an opportunity for teachers to share concerns about a change process, consider and promote alternative approaches, and provide professional support for the community members as the change is experienced. PLCs engage teachers in authentic, embedded professional development, thus contributing to professional learning and improved student outcomes (Darling-Hammond, Chung Wei, Andree, Richardson, \& Orphanos, 2009). Had Bart truly embraced the concept of personalizing written report comments as Rachel thought he had, he would have been demonstrating shared leadership through recognition of his ownership in this professional learning community. By investing in the PLC to improve his 
skills, Bart would have been able to effectively write report comments that would have generated a greater feeling of self-efficacy (Wahlstrom \& Seashore Louis, 2008). As a senior teacher in the school, Bart is respected by his peers. His negligence in fully engaging in the PLC or readily engaging in the SIP demonstrates that he still has much to learn. His resistance to the change process not only harmed his professional abilities as a teacher but may have had a negative ripple effect on those who teach with him.

Reflection and Change

Moving forward from this experience, Rachel would have much to gain from incorporating an element of reflection into her professional practice. Clearly, at the moment that Bart confronts her, Rachel will not be engaging in critical reflection on what she has done since time is a critical aspect in reflection (Gardiner \& Tenuto, 2015). Going forward, Rachel will benefit from contemplating the confrontation, what led to it, and what she can do differently in the future. This type of contemplative reflection can alter one's practices and ultimately have a positive impact on student achievement (Corcoran, 2017; Wright, 2009). Rachel also has the opportunity to confront and coach Bart about the inappropriate nature of his report card comments and how he responded to Rachel's changing of the comments. Given the longstanding relationship that the two have had, Rachel has an opportunity to engage Bart in a discussion about his limited involvement in the PLC, the significance of the SIP, and the importance of conversations that are courageous and courteous.

Beyond her own personal reflective ability, Rachel has the opportunity to engage with the two other members of the administrative team to foster her ability to critically reflect on her practice. Seasoned principals can provide input and advice that could have helped in avoiding a situation where Rachel engaged in re-writing Bart's report card remarks. The portfolio of the 
school administrator involves instructional leadership, including the formalized reporting of student achievement. In this active leadership role, the principal becomes an advocate for the professional standards of practice guiding teachers to meet the required expectations for reporting. Although the principal was seasoned, he was nearing retirement and had delegated this leadership responsibility with reporting to a junior administrator without the mentorship that would have helped prepare Rachel for situations such as the one that she had encountered. If the principal had been more actively engaged with mentoring Rachel, she would have the opportunity to gain insight into best practices with assessment and evaluation report writing with teaching staff (Wahlstrom \& Seashore Louis, 2008; White-Smith \& White, 2009). Additionally, a stronger mentoring framework would have given her exposure to successful models of shared leadership implementation through direct practice (Pashiardis et al., 2012). Thus, effective school principals enable the successful transition of leadership characterized by improving selfefficacy within a shared framework of transformation (White-Smith \& White, 2009; Wright, 2009).

\section{Discussion Questions}

1. What issues related to professional ethics does the case raise?

2. What role does the principal, as the lead administrator, play in the case?

3. What are some ways that principals and vice-principals can build trust with faculty when they are often in schools for abbreviated periods of time?

4. Why might a teacher be resistant to a change as mundane as written report card comments? 
5. How can principals and teachers work for positive change when they may not agree on fundamental issues?

6. In what way can student and parent/guardian voice impact the work of principals and teachers? If a student such as Darren, who is referred to in this case, had been more actively involved with Bart and Rachel, might it have changed the incident or the exchange that took place between Bart and Rachel?

7. Are there voices that are not present in this case? Are certain perspectives more strongly presented? How might you aim for a balanced perspective when considering the different voices and perspectives?

Class Activities and Resources

1. Engage in a think-pair-share (think quietly for a minute, pair up with another person, share your responses) about a time when you had to respond to a difficult situation as a principal or teacher. Describe the situation and identify key issues that led to the difficult situation. After describing the situation, the second person in the pair should provide quick feedback on their perceptions of the situation. Finish with describing the long-term impact of the decisions that were made and together analyze alternative solutions that could have occurred.

2. Role play in groups of three the following situation: Bart has just left Rachel's office. Role play what you would now do to try and bring a healthy resolution to the situation that would include an attempt to restore trust between Rachel and Bart. One person will role play Rachel, one Bart, and one the principal.

3. Share a metaphor or analogy with a classmate that reflects your view on trust in school relationships. For example, "When I think of trust in a school, I think of a person jumping 
out of a plane with a parachute. I have every reason to believe that the parachute will open when I require it. However, I also know that there is an element of risk. I trust the parachute will open just like I trust that my colleagues will support me when I start a new initiative."

4. The case focuses on trust and communication in a school community. Describe another school-based situation where you have you seen a break-down in trust and/or communication. Analyze the example you provide to understand the reasons that trust and communication broke down.

5. Read the article by Author (2017) that describes how principals experience critical incidents and how these foster their leadership perspectives. Discuss with your classmates a critical incident (see the definition in the article) and how the incident impacted your view of leadership, teaching, or learning.

6. Check out this checklist for having courageous conversations as a principal (http://www.edu.gov.on.ca/eng/policyfunding/leadership/pdfs/TipSheetConversation.pdf. Add an eighth principle for "fierce conversations" that you have learned from your experience. Share the principle you have developed with a classmate and explain why this principle is important to you.

7. Few would argue that the work of a principal is hurried and pressure-filled. In groups, identify strategies to help ensure that the demands of the job do not lead to poorly considered decisions. 


\section{References}

Author. (2017).

Bai, Y., Ping Li, P., \& Xi, Y. (2012). The distinctive effects of dual-level leadership behaviors on employees' trust in leadership: An empirical study from China. Asia Pacific Journal of Management, 29, 213-237.

Bernhardt, V. (2015). Data, data everywhere: Bringing all the data together for continuous school improvement. New York, NY: Routledge.

Corcoran, R. P. (2017). Preparing principals to improve student achievement. Child \& Youth Care Forum, 46(5), 769-781.

Darling-Hammond, L., Chung Wei, R., Andree, A., Richardson, N, \& Orphanos, S. (2009). Professional learning in the learning profession: A status report on teacher development in the United States and abroad. Dallas, TX: National Staff Development Council.

Eyal, O. \& Roth, G. (2011). Principals’ leadership and teachers' motivation. Journal of Educational Administration, 49(3), 256-275.

Gardiner, M. E., \& Tenuto, P. L. (2015). Reflections of practicing school principals on ethical leadership and decision-making: Confronting social injustice. The Journal of ValuesBased Leadership, 8(2), Retrieved from:

https://scholar.valpo.edu/cgi/viewcontent.cgi?article=1127\&context=jvbl

Gregory, J. L. (2017). Trust relationships in schools: Supporting or subverting implementation of school-wide initiatives. School Leadership \& Management, 37(1-2), 141-161.

Gurr, D., Drysdale, L., \& Mulford, B. (2005). Successful principal leadership: Australian case studies. Journal of Educational Administration, 43(6), 539-551.

Handford, V. \& Leithwood, K. (2013). Why teachers trust school leaders. Journal of 
Educational Administration, 51(2), 194-212.

Helstad, K. \& Moller, J. (2013). Leadership as relational work: Risks and opportunities. International Journal of Leadership in Education, 16(3), 245-262.

Moller, J. \& Eggen, A. (2005). Team leadership in upper secondary education. School Leadership and Management, 25(4), 331-347.

Moolenaar, N., Daly, A., \& Sleegers, P. (2010). Occupying the principal position: Examining relationships between leadership, social network position and schools' innovative climate. Educational Administration Quarterly, 46(5), 623-670.

Mullen, C. A. (2017). What's ethics got to do with it? Pedagogical support for ethical student learning in a principal preparation program. Journal of Research on Leadership Education, 12(3), 239-272.

Northfield, S. (2013). The novice principal: Change and challenges. Canadian Journal of Educational Administration and Policy, 142, 158-182.

Pashiardis, P., Kafa, A., \& Marmara, C. (2012). Successful secondary principalship in Cyprus: What have "Thucydides" and "Plato" revealed to us? International Journal of Educational Management, 26(5), 480-493.

Poulou, M. S. (2017). An examination of the relationship among teachers' perceptions of socialemotional learning, teaching efficacy, teacher-student interactions, and students' behavioral difficulties. International Journal of School \& Educational Psychology, 5(2), 126-136.

Tschannen-Moran, M. (2014). Trust matters: Leadership for successful schools (2 ${ }^{\text {nd }}$ Ed.). San Francisco, CA: Jossey-Bass. 
Tschannen-Moran, M., \& Gareis, C. R. (2015). Principals, trust, and cultivating vibrant schools. Societies, 5(2), 256-276.

Van Maele, D. \& Van Houtte, M. (2012). The role of teacher and faculty trust in forming teachers' job satisfaction: Do years of experience make a difference? Teaching and Teacher Education, 28, 879-889.

Wahlstrom, K. \& Seashore Louis, K. (2008). How teachers experience principal leadership: The roles of professional community, trust, efficacy and shared responsibility. Educational Administration Quarterly, 44(4), 458-495.

Walker, K., Kutsyuruba, B. \& Noonan, B. (2011). The fragility of trust in the world of school principals. Journal of Educational Administration, 49(5), 471-494.

Watson, C. (2014). Effective professional learning communities? The possibilities for teachers as agents of change in schools. British Educational Research Journal, 40(1), 18-29.

White-Smith, K. \& White, M. (2009). High school reform implementation: Principal's perceptions on their leadership role. Urban Education, 44(3), 259-279.

Wright, L. (2009). Leadership in the swamp: Seeking the potentiality of school improvement through principal reflection. Reflective Practice, 10(2), 259-272. 
ERIC descriptors:

Transformational Leadership

Trust (psychology)

School Effectiveness 